International Journal of Agriculture and Environmental Research

ISSN: 2455-6939

Volume: 07, Issue: 03 "May-June 2021"

\title{
THE DIFFUSION OF CULTIVATOR MACHINE INNOVATION
}

\author{
Jabal Tarik Ibrahim, Ary Bakhtiar, Dianingtyas Fidela Afifah \\ Study Program of Agribusiness, Faculty of Agriculture and Animal Science, Universitas \\ Muhammadiyah Malang, Malang 65144, East Java, Indonesia \\ DOI: https://doi.org/10.51193/IJAER.2021.7301
}

\begin{abstract}
The development of the agricultural sector is carried out as an attempt to implement changes leading to economic growth and public welfare. The diffusion of agricultural innovations is a pivotal issue that needs to be addressed in the development. This research aims at describing the diffusion stages of cultivator machine innovation and scrutinizing the effect of innovation characteristics on cultivator machine adoption on vegetable farmers in Banyuroto Village, Sawangan Subdistrict, Magelang Regency. The data were collected by means of questionnaires, direct and phone interviews, and observation. The data were analyzed using two methods, i.e., descriptive analysis and multiple linear regression analysis. The findings showed that the diffusion stages of cultivator machine innovation began with an initial stage of promoting knowledge of cultivator machine through training provided by agricultural extension agents to Karya Makmur's Livestock Farmer Group in 2017, followed by process of persuasion (i.e., the response of farmers' interest to cultivator machines). The decision stage was indicated by the attitude of adopting or rejecting the cultivator machine innovation. Furthermore, the implementation stage began with the use of cultivator machines for cultivating the land in 2019. Lastly, the confirmation stage was in the form of repeated use. The results of the statistical analysis demonstrated that innovation characteristics simultaneously influenced cultivator machine adoption. The variables influencing cultivator machine adoption were relative advantages, trialability, and observability. Meanwhile, the variables that did not influence were compatibility and complexity.
\end{abstract}

Keywords: Adoption, Cultivator, Diffusion, Innovation, Technology

\section{INTRODUCTION}

Rural areas cannot develop without agricultural development since 90 percent of the rural population use the agricultural sector as their primary income source (Udemezue, J.C.; Osegbue, 2018). According to Silaban and Sugiharto (2016), the agricultural sector is considered 
International Journal of Agriculture and Environmental Research

ISSN: $2455-6939$

Volume: 07, Issue: 03 "May-June 2021"

developed when farmers have applied agricultural technology, both in equipment and farming methods. The adoption of such new technology cannot be separated from the initial process known as the diffusion of innovation. According to Sebastião (2019), the diffusion of innovation is a process by which innovation is disseminated from time to time in society (social systems) through certain communication channels.

One of the diffusions of agricultural innovations applied in Magelang Regency is the cultivator machine technology. This technology is applied in several subdistricts in Magelang Regency, one of which is in Banyuroto Village, Sawangan Subdistrict. Data from the Central Bureau of Statistics of Magelang Regency (2018) showed that 1,978 of 4,048 village residents work as farmers.

Farmers are highly responsive to agricultural technologies to assist their agricultural activities. It is realized by the innovation implementation of the cultivation of strawberries in BanyurotoAgro-tourism through the use of superior seeds, pest control tools, and cultivator machines to overcome labor scarcity (Aristya et al., 2017). The diffusion of cultivator machine innovation through various technological stages is acceptable to farmers. Their response to the cultivator machine varies. Not all of them can accept this technological innovation easily. Some farmers require a longer process to accept it; therefore, due to such a problem, this research is of importance to be carried out.

This research aims at 1) describing the diffusion stages of cultivator machine innovation and 2) scrutinizing the effect of innovation characteristics on cultivator machine adoption on vegetable farmers in Banyuroto Village, Sawangan Subdistrict, Magelang Regency.

\section{METHODS}

This research employed quantitative descriptive methods. The research was carried out in Banyuroto Village, Sawangan Subdistrict, Magelang Regency. The respondents used were farmers who had used cultivator machines in cultivating their land. Samples were selected using a simple random sampling method. Slavin's formula was used to determine the number of samples:

Information:

$$
\begin{array}{ll}
n=\frac{427}{1+427\left(0,1^{2}\right)} \text { (Susanti et al., 2019) } & n=\text { Total samples taken } \\
& \mathrm{N}=\text { Total cultivator users } \\
n=81.0=81 \text { samples } & \mathrm{d}=\text { Error tolerance }
\end{array}
$$


Based on the formula above, the number of respondents was 81 . The data were collected by means of questionnaires, direct and phone interviews, and observation. The data collected using the ordinal scale was converted to the interval scale using the successive interval method. The data converted to the interval scale were subsequently tested for normality, multicollinearity, and heteroscedasticity. The diffusion stages of cultivator machine innovation were elaborated descriptively and qualitatively. The effect of innovation characteristics on cultivator machine adoption was analyzed using multiple linear regression analysis as follows:

$\mathrm{Y}=\mathrm{b} 0+\mathrm{b} 1 \mathrm{X} 1+\mathrm{b} 2 \mathrm{X} 2+\mathrm{b} 3 \mathrm{X} 3+\mathrm{b} 4 \mathrm{X} 4+\mathrm{b} 5 \mathrm{X} 5+\mathrm{bnXn}(\mathrm{Ibrahim}, 2020)$.

Information:

$\mathrm{y} \quad=$ Innovation Adoption

b0 = Intercept

b1...b5 = Regression Coefficient

$\mathrm{X} 1=$ Relative Advantages

$\mathrm{X} 2=$ Compatibility

$\mathrm{X} 3=$ Complexity

$\mathrm{X} 4=$ Trialability

$\mathrm{X} 5=$ Observability

\section{RESULTS AND DISCUSSION}

\section{a. The Diffusion Stages of Cultivator Machine Innovation}

Everett M. Rogers, in his book (1983), elaborates that there are five diffusion stages of innovation, i.e., knowledge, persuasion, decision, implementation, and confirmation. The diffusion stages of cultivator machine innovation are illustrated in the following figure: 


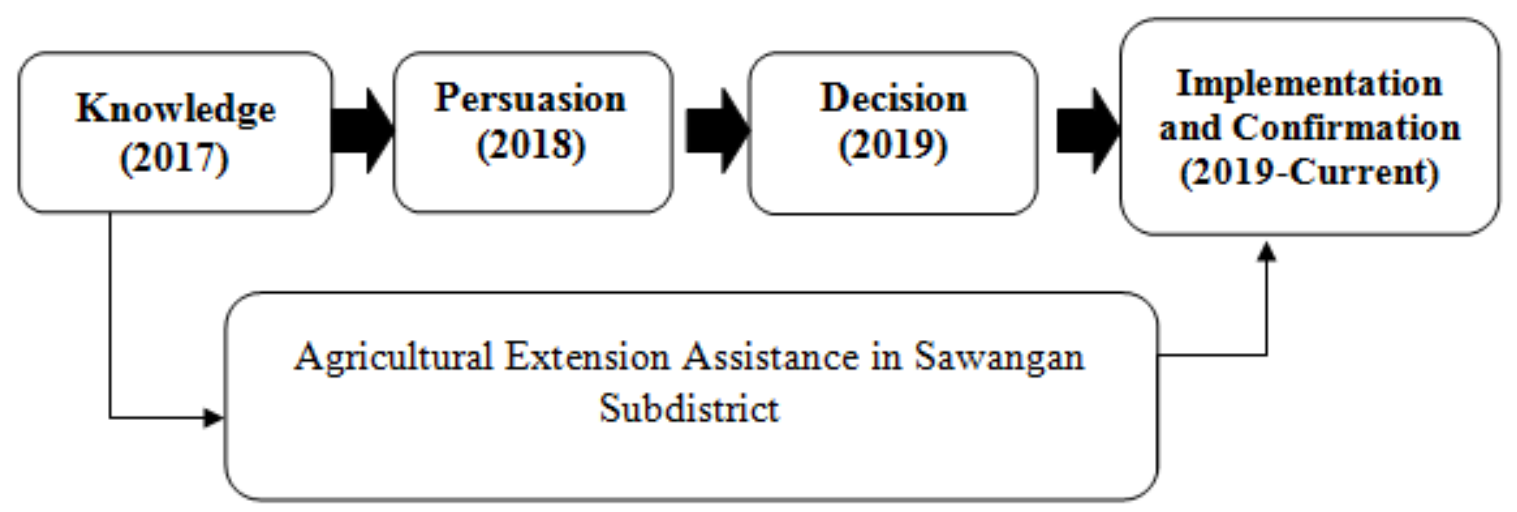

Figure 1: The diffusion stages of cultivator machine innovation in Banyuroto Village, Sawangan Subdistrict, Magelang Regency.

\section{1). Knowledge}

Agricultural extension agents of Sawangan Regency introduced the cultivator machine in 2017. Mr. Surya, as one of the agricultural extension agents in Banyuroto Village, disseminated information on agricultural innovations, such as grass choppers and cultivator machines. Based on the information dissemination, a cultivator machine is a machine used to cultivate the land. This diesel-fueled engine functions to loosen the soil.

\section{2). Persuasion}

Based on the information dissemination in 2017, both farmers and members of the farmer group showed an interest in cultivator machines. They expected these machines to be implemented in Banyuroto Village to ease and fasten land cultivation in a more cost-effective and timely manner and overcome labor scarcity.

\section{3). Decision}

According to farmers, cultivator machines had a positive impact. The residents of Banyuroto Village were not reluctant to new agricultural innovations. In 2018, extension agents mentored the formulation of the procurement proposal for cultivator machines submitted to the Regent of Magelang Regency.

4). Implementation

The proposal in 2018 successfully procured a unit of cultivator machine in 2019. Farmers started implementing the cultivator machine in their agricultural land. Initially, it was the chief of the farmer group who used the cultivator machine; but then, his members followed. Based on the observation, the number of cultivator machines in Banyuroto Village was minimal. Not all 
farmers could buy it. The farmer group then took the initiative to provide cultivator machine rental services. Tenant farmers solely paid the cost of fuels and labor.

The agricultural extension agents were innovators who initiated, disseminated information, and provided training. Members of the farmer group were the early recipients. Vegetable farmers who used cultivator machines after the farmer group were called the early majority. In 2020, cultivator machines began being used in a broader community called the underdeveloped majority. The last recipients, namely farmers who were reluctant to the cultivator machines, were called laggards.

\section{5). Confirmation}

The implementation of cultivator machines gave two choices for farmers to cultivate their land, i.e., switching to use a cultivator machine or continuing to use a hoe. The results of the interview regarding the use of cultivator machines are as follows:

Table 1: Confirmation of Cultivator Machine Adoption

\begin{tabular}{lccccc}
\hline \multirow{1}{*}{ Statement } & \multicolumn{5}{c}{ Score } \\
\cline { 2 - 6 } & SD & D & U & A & SA \\
\hline $\begin{array}{l}\text { I think of using cultivator machines every } \\
\text { time I cultivate the land }\end{array}$ & 0 & 7 & 20 & 36 & 17 \\
\hline
\end{tabular}

Source: Primary Data processed in 2021

Information:

SA $\quad=$ Strongly Agree

A $\quad=$ Agree

$\mathrm{U} \quad=$ Uncertain

$\mathrm{D} \quad=$ Disagree

$\mathrm{SD}=$ Strongly Disagree

Table 1 demonstrates that 36 of 81 respondents agreed to use a cultivator machine. Twenty respondents were uncertain. Several considerations obtained from the interview include:

1. The location of the lands was on the slopes of Mount Merbabu.

2. Lands were sloping.

3. The road access was not easily passed by machines.

4. The cost incurred was higher than using a hoe. 
The diffusion stages of cultivator machine innovation are inseparable from the diffusion aspects of innovation. The agricultural innovation introduced was the cultivator machine. Communication channels used were those of between groups and individuals. The period from the knowledge stage to the confirmation stage of cultivator machine adoption was less than two years (2017-2019). The social system targeted was vegetable farmers in Banyuroto Village, Sawangan Subdistrict, Magelang Regency.

\section{b. The Effect of Innovation Characteristics on Cultivator Machine Adoption}

\section{1). The Simultaneous Effect of Innovation Characteristics on Cultivator Machine Adoption}

The simultaneous effect of innovation characteristics on cultivator machine adoption was tested based on the $\mathrm{F}$ test and the coefficient of determination $\left(\mathrm{R}^{2}\right)$ test as follows:

Table 2: The Results of the $F$ Test and the Coefficient of Determination $\left(R^{2}\right)$ Test

\begin{tabular}{cccccc}
\hline \multirow{2}{*}{ Model } & \multicolumn{5}{c}{ Score } \\
\cline { 2 - 5 } & Sig. & $\boldsymbol{\alpha}(\mathbf{0 , 0 5})$ & F count & F table & R Square \\
\hline Regression & 0.000 & 0.05 & 19.490 & 2.33 & 0.565 \\
\hline \multicolumn{5}{c}{ Source: Statistical Test Results processed in 2021}
\end{tabular}

Table 2 showed that the significance value (0.000) was smaller than the $\alpha$ value $(0.05)$ and the $F$ count (19.490) was greater than the F table. Based on the results, the relative advantages (X1), compatibility (X2), complexity (X3), trialability (X4), and observability (X5) simultaneously influenced cultivator machine adoption (Y).

Table 2 showed that the R Square value was 0.565 . Based on the coefficient of determination $\left(\mathrm{R}^{2}\right)$ test results, the variable of innovation characteristics could simultaneously explain the variable of cultivator machine adoption (Y) by 0.565 (56.5\%), while the remaining 43.5 was influenced by other variables not included in this research.

These results showed that the innovation characteristics had a significant effect on cultivator machine adoption. It is consistent with Rogers' diffusion of innovation theory (1983), stating that innovation characteristics were one of the determinants of innovation adoption. According to Zhang et al. (2015), innovation characteristics highly related to the adoption possibility include innovations that are considered beneficial, compatible with existing needs, testable in a limited time before being used, and observable for its results. The results of this research also support the previous research asserting that innovation characteristics influenced adoption decisions (Vagnani \& Volpe, 2017).

The results of multiple linear regression analysis are presented in the following table: 
International Journal of Agriculture and Environmental Research

ISSN: 2455-6939

Volume: 07, Issue: 03 "May-June 2021"

Table 3: Multiple Linear Regression Test Results

\begin{tabular}{|c|c|c|}
\hline \multirow{2}{*}{ Variable } & \multicolumn{2}{|c|}{ Score } \\
\hline & $\beta$ & Sig. \\
\hline Constant & -0.818 & \\
\hline Relative advantages & 0.309 & 0.05 \\
\hline Compatibility & 0.118 & 0.05 \\
\hline Complexity & 0.058 & 0.05 \\
\hline Trialability & 0.367 & 0.05 \\
\hline Observability & 0.195 & 0.05 \\
\hline
\end{tabular}

Source: Statistical Test Results processed in 2021

Based on Table 3, it produces the following regression equation:

$\mathrm{Y}=-1.818+0.309 \mathrm{X} 1+0.118 \mathrm{X} 2+0.058 \mathrm{X} 3+0.367 \mathrm{X} 4+0.195 \mathrm{X} 5$

a. The constant value was -1.818 indicating that if the value of relative advantages (X1), compatibility (X2), complexity (X3), trialability (X4), and observability (X5) was zero (0), the value of innovation adoption $(\mathrm{Y})$ was -1.818 .

b. The coefficient value of the relative advantage variable ( $\beta 1$ ) was 0.309 (positive value) indicating that the higher (by 1) the relative advantages (X1), the more increasing the innovation adoption by 0.309 .

c. The coefficient value of the relative advantage variable ( $\beta 1)$ was 0.309 (positive value) indicating that the higher (by 1) the compatibility (X2), the more increasing the innovation adoption by 0.118 .

d. The coefficient value of the complexity variable ( $\beta 3$ ) was 0.058 (positive value) indicating that the higher the complexity (X3), the more increasing the innovation adoption.

e. The coefficient value of the trialability variable ( $\beta 4$ ) was 0.367 (positive value) indicating that the higher (by 1) the trialability (X4), the more increasing the innovation adoption by 0.367 .

f. The coefficient value of the observability variable ( $\beta 5$ ) was 0.195 (positive value) indicating that the higher (by 1) the observability (X5), the more increasing the innovation adoption by 0.195 .

\section{2). The Partial Effect of Innovation Characteristics on Cultivator Machine Adoption}

The results of the t-test for the partial effect of innovation characteristics on cultivator machine adoption are presented in the following table: 
International Journal of Agriculture and Environmental Research

ISSN: $2455-6939$

Volume: 07, Issue: 03 "May-June 2021"

Table 4: t-test Results

\begin{tabular}{lcccc}
\hline \multirow{2}{*}{ Variable } & \multicolumn{3}{c}{ Score } & \\
\cline { 2 - 5 } & Sig. & $\boldsymbol{\alpha ( 0 . 0 5 )}$ & t count & t table \\
\hline Relative advantages & 0.003 & 0.05 & 3.036 & 1.668 \\
Compatibility & 0.220 & 0.05 & 1.112 & 1.668 \\
Complexity & 0.538 & 0.05 & 0.619 & 1.668 \\
Trialability & 0.001 & 0.05 & 3.363 & 1.668 \\
Observability & 0.053 & 0.05 & 1.969 & 1.668 \\
\hline
\end{tabular}

Source: Statistical Test Results processed in 2021

Table 4 showed that the significance value of relative advantages (X1) and observability (X5) used was smaller than the $\alpha$ value (0.05) while the $\mathrm{t}$ count value was greater than the $\mathrm{t}$ table value. The significance value of compatibility (X2) and complexity (X3) was greater than 0.05 , and the $t$ count value of these three variables was smaller than the $t$ table value. In contrast to trialability $(\mathrm{X} 4)$, the results showed that the significance value was greater than 0.05 , and the $\mathrm{t}$ count value was greater than the $t$ table value. Based on the decision criteria, the effect of innovation characteristics on cultivator machine adoption is as follows:

\section{a. Relative Advantages (X1) Influenced Cultivator Machine Adoption (Y).}

The relative advantages variable significantly influenced cultivator machine adoption on vegetable farmers in Banyuroto Village, Sawangan Subdistrict, Magelang Regency. The interview results suggested that respondents considered that cultivator machines provided economic benefits, new experiences of cultivating land in a moreeffortless and efficient way possible in terms of time, cost, and labor. Time-saving in this regard refers to a faster-cultivating process compared to that of using a hoe. Less labor is required and therefore, so are the costs incurred. These results correspond to Rogers' diffusion of innovation theory (1983), stating that the relative advantages influence innovation adoption, especially at the diffusion stages of innovation. It also confirms Scott \& McGuire's findings (2017), asserting that innovation provides advantages in current and future practices.

\section{b. Compatibility (X1) Influenced Cultivator Machine Adoption (Y).}

The compatibility variable did not influence cultivator machine adoption on vegetable farmers in Banyuroto Village, Sawangan Subdistrict, Magelang Regency. The fulfillment of the compatibility needs of innovation can be seen from its compatibility with the prevailing values, culture, and experiences in the social system. These results do not correspond to Rogers' diffusion of innovation theory (1983), stating a relationship between compatibility and 
innovation adoption. It was due to the incompatibility in terms of price, cost capability, road accessibility, and landscondition (i.e., on the slopes of Mount Merbabu).

\section{c. Complexity (X1) Influenced Cultivator Machine Adoption (Y).}

The complexity variable did not significantly influence cultivator machine adoption perceived from the ease of use, maintenance, and spare-part availability. These results are not in line with Rogers' diffusion of innovation theory (1983). In theory, complexity influenced innovation adoption, especially at the diffusion stages of innovation. Previous research by Zhang et al. (2015) confirms the results of this research since complexity had no influence due to different factors.

\section{d. Trialability (X4) Influenced Cultivator Machine Adoption (Y).}

The trialability variable significantly influenced cultivator machine adoption. Trialability was measured from whether or not farmers ever used and rented a cultivator machine before selfimplementing it on a narrow land.

Based on the indicators, these findings are not consistent with the previous research (Zhang et al., 2015), showing that trialability is less important in determining adoption decisions. This seems plausible since respondents are farmers who need role models and practices of using a cultivator machine. It requires visible advantages before other farmers started adopting the use of cultivator machines.

\section{e. Observability (X4) Influenced Cultivator Machine Adoption (Y).}

The observability variable, based on its significance value, did not influence cultivator machine adoption. In contrast to $\mathrm{t}$ count and $\mathrm{t}$ table values, observability significantly influenced cultivator machine adoption. Since the significance value rounded did not significantly influence the figure of 0.05, it concludes that the hypothesis is accepted. According to Rogers (2003), observability is how others see the results of using innovation. Observability in this research was measured based on 1) the beds processed by cultivator machines, whether or not beds look neat, cleaner, and maximally utilized, and 2) the use of cultivator machines throughout the day and how they are able to save labor.

\section{CONCLUSION}

\section{a. This research concludes:}

The diffusion stages of cultivator machine innovation began with an initial stage of promoting knowledge of cultivator machines through training in 2017. The persuasion stage in 2018 showed that members of the farmer group showed an interest in cultivator machines. The 
decision stage was realized through the formulation of the procurement proposal for cultivator machines submitted to the Regent of Magelang Regency. In 2019, a unit of cultivator machine was received and implemented by vegetable farmers in Banyuroto Village to cultivate their agricultural lands. The confirmation stage was realized through the repeated use of cultivator machines since 2019 .

\section{b. Factors influencing cultivator machine adoption include:}

1. Relative advantages

Cultivator machines provide economic benefits and new experiences of cultivating land in a more effortless and efficient way possible in terms of time, cost, and labor. Therefore, it can be considered that relative advantages influenced cultivator machine adoption.

2. Trialability

Trialability influenced cultivator machine adoption since farmers generally need role models and practices of using a cultivator machine.

3. Observability

Observability influenced cultivator machine adoption. It can be seen from the way how visible advantages obtained after using the cultivator machine emerge as an example for others to start adopting it.

\section{c. Factors that did not influence cultivator machine adoption include:}

1. Compatibility

Cultivator machines were perceived as less compatible with existing needs, such as the incompatibility in terms of price, cost capability, road accessibility, and lands condition (i.e., on the slopes of Mount Merbabu).

2. Complexity

Cultivator machines were considered less complex. Some respondents merely rent machines without directly using them; therefore, the complexity of the machines did not significantly influence cultivator machine adoption.

\section{REFERENCES}

Aristya, G. R., Sasongko, A. B., Hidayati, L., \& Setiawan, A. (2017). Implementasi Inovasi Budidaya Stroberi di Agrowisata Banyuroto Kabupaten Magelang Melalui Education for Sustainable Development. Jurnal Pengabdian Kepada Masyarakat (Indonesian Journal of Community Engagement), 2(2), 125-132. https://doi.org/10.22146/jpkm.26500 
International Journal of Agriculture and Environmental Research

ISSN: 2455-6939

Volume: 07, Issue: 03 "May-June 2021"

Badan Pusat Statistik Kabupaten Magelang. (2018). Kecamatan Sawangan Dalam Angka 2018 (Badan Pusat Statistik Kabupaten Magelang (ed.)). BPS Kabupaten Magelang. https://doi.org/1102001.3308090

Ibrahim, Jabal T. (2020). Metode Penelitian Sosial Ekonomi Pertanian. UMM Press.

Rogers, E. M. (1983). diffusion of inovation fourth edition.pdf (Fourth). FREE PRESS. http://www.simonsays.com

Rogers, E. M. (2003). diffusion of inovation fifth edition.pdf (fifth). FREE PRESS. http://www.simonsays.com

Scott, S., \& McGuire, J. (2017). Using Diffusion of Innovation Theory to Promote Universally Designed College Instruction. International Journal of Teaching and Learning in Higher Education, 29(1), 119-128.

Sebastião, S. A. (2019). Innovation and the Diffusion of Technology in Agriculture in Floodplains in the State of Amazonas Inovação e Difusão de Tecnologia na Agricultura de Várzea na Amazônia. May, 619-635.

Silaban, L. R., \& Sugiharto, S. (2016). Usaha Usaha yang dilakukan Pemerintah dalam Pembangunan Sektor Pertanian. JPPUMA: Jurnal Ilmu Pemerintahan Dan Sosial Politik UMA (Journal of Governance and Political Social UMA), 4(2), 196-210.

Susanti, A., Soemitro, R. A. A., Suprayitno, H., \& Ratnasari, V. (2019). Searching the Appropriate Minimum Sample Size Calculation Method for Commuter Train Passenger Travel Behavior Survey. Journal of Infrastructure \& Facility Asset Management, 1(1), 47-60. https://doi.org/10.12962/jifam.v1i1.5232

Udemezue, J.C.; Osegbue, E. G. (2018). Theories and Models of Agricultural Development Agricultural Development. Annuals of Reviews and Research, 1(5), 4. https://juniperpublishers.com/arr/pdf/ARR.MS.ID.555574.pdf

Vagnani, G., \& Volpe, L. (2017). Innovation attributes and managers' decisions about the adoption of innovations in organizations: A meta-analytical review. International Journal of Innovation Studies, 1(2), 107-133. https://doi.org/10.1016/j.jiis.2017.10.001

Zhang, X., Yu, P., Yan, J., \& Ton A M Spil, I. (2015). Using diffusion of innovation theory to understand the factors impacting patient acceptance and use of consumer e-health innovations: A case study in a primary care clinic Healthcare needs and demand. BMC Health Services Research, 15(1), 1-15. https://doi.org/10.1186/s12913-015-0726-2 